\title{
ISLAM, DEMOCRACY, AND THE QUESTION OF COEXISTENCE
}

\author{
Shah M. Nister Jahan Kabir
}

\begin{abstract}
Islam and Islamic culture are the subjects of discussions and debates around the world. Often these discussions have been connected to immigration in general and the policies of assimilation and integration and, by extension, to the co-existence of different religious and ethnic groups and the practice of racism and racial segregation in particular. Thus these issues have now become prominent in the fields of cultural, religious and migration studies and in studies on race relations and socio-economic inequalities. For instance, people inside and outside of academia are questioning Islamic politics, the place of democracy and human rights in Islam, and crucially whether Islam can coexist with other (i.e. Western) cultures. Against this background, it is important to understand the Islamic cultural system, Islamic society and politics, including democracy, in Islam, the Muslims' views on migration, and some other phenomena associated with Islam. This article will discuss Islamic norms and values regarding current questions and search for the place of political Islam, democracy in Islam and whether Islam can coexist with other cultures.
\end{abstract}

\section{Introduction}

The current debate about Islam or Muslims, throughout the world, and especially in Europe, has a high profile. The debate is concerned with cultural conflicts, state relations with some predominantly Muslim countries, Islamic values and symbols, and Muslim migration to the West. Military action by the United States and some other Western nations, in the name of the "war on terror" in Iraq and in efforts to capture Osama bin Laden in Afghanistan, has sharpened the perception that there is a clash between the West and Islam. ${ }^{1}$ Samuel Huntington ${ }^{2}$ suggests that "relations between societies in the coming decades are more likely to reflect their cultural commitments" and holds that the West is culturally different from the Orient and that there is a clash between these two. In parallel, worldwide discussion, including academic work and dialogue, has increasingly focused on supposedly Islamic or

* Shah M. Nister J. Kabir is a PhD candidate in the Department of Media, Film and Communication at the University of Otago, New Zealand. He would like to thank Dr Simon Rae (University of Otago) for assistance in developing and presenting the argument of this article.

ICR 2.3 Produced and distributed by Pluto Journals ICR.plutojournals.org 
Muslim issues. Therefore, issues relating to Islam and the West have become intermingled in discussions inside and outside of academia. ${ }^{3}$

Therefore, it is important to understand the Islamic cultural system, Islamic society and politics, including democracy in Islam, Muslims' views on migration, $j i h \bar{a} d$ as a norm, and some other phenomena associated with current global issues and symbolised as being Islamic.

To approach the discussion, this article poses some questions: (a) is Islam compatible with democracy? (b) what is the place of politics in Islam? To clarify the discussion of these questions and the answers to them some other issues will be addressed.

\section{Discussion}

Islam and Islamic culture are the subjects of discussions around the world. To the West, Islam is entangled with fanaticism, fundamentalism, militancy and terrorism. ${ }^{4}$ Consequently, people in the West now use 'fundamentalism' to mean Islam or Muslim activists, where they once used it to identify conservative Christianity. ${ }^{5}$ The term 'Islamophobia' is used to refer to attitudes to Islamic culture, in the context of Muslim militancy, terrorism, etc. Because of this, interpretations of Islam and Muslim culture have shifted to focus on Islamist activists and Islamic fundamentalists. Therefore, people inside and outside of academia are questioning Islamic politics $^{6}$ and maintain that "religion is a cohesive and unitary force and that it independently shapes politics, and it has been fuelled by the consequent efforts to specify the (implicitly unique) political role of Islam". ${ }^{7}$ Others propose that Islam can accommodate democracy, and political Islam and the Islamic faith need to be understood at a deeper level. ${ }^{8}$ This debate was born outside academia and social research, and has occupied public attention towards politics, media and certain religious issues. It has now gained prominent attention in the fields of cultural, religious and migration studies and in relation to socio-economic and race relations approaches. Also, currently Islam is an instrument of politics in Muslim countries and in the West (for example, politicians in predominantly Muslim countries make arguments against the West, and Western politicians promote xenophobic fears) where it has become a factor in goal attaining techniques. In addition, Islam has been used in the pursuit of political power, by dictators and democrats alike, and is often used to maintain power that is strikingly un-Islamic in character. ${ }^{9}$

In this connection, multiculturalism is another term which has deep roots in approaches to addressing prejudice and is also frequently used in discussions concerning Islam or Muslims. Discussing the theoretical roots of this term, scholars suggest that it is ill-defined, ${ }^{10}$ controversial and contested. ${ }^{11}$ However, the idea of multiculturalism helps to give minority groups a platform on which to build 
recognition of their own cultural tradition and identity among a nation's mainstream cultural groups. ${ }^{12}$ For a soundly conceptualised multicultural global public sphere, however, a society needs to be dialectical in its thinking and should aim to bring all groups in a society into confluence. This scientific co-existing social environment can be built up through cultural interchanges between different civilisational traditions and "by interrogating and respecting a range of different cultural notions of the public, citizenship, representation, human rights and democracy". ${ }^{13}$ However, these issues are far from being settled and debate is ongoing in what has become a smouldering standoff.

Recognising the current debate in the world concerning Muslim identity, Stauth ${ }^{14}$ holds that after the fall of socialism Islam appeared on the stage of world history again and reoccupied its strong and important position in global politics. In this process, relations between the West and Islam appeared to be as those between hostile entities: Islam as religious and traditional; the West as secular, modern and rational. ${ }^{15}$ However, "the variety of religious symbolizations and practices that has emerged with great differences from place to place and from generation to generation shows the openness with which Muslims have again and again searched for an adequate answer to their specific social situation and time". ${ }^{16}$ On the other hand, Stauth ${ }^{17}$ notes that a sociologically conceptualised Islam is yet to be studied within the framework of cultural self-assertiveness, and therefore Islamic reformation and Arab culturalism remain hidden in the dark. This is a cause of misunderstanding about Islam.

\section{Democracy and Islam}

As addressed, some scholars debate whether Islam is compatible with democracy and human rights, a perception mainly enrooted in political Islam, Islamic law

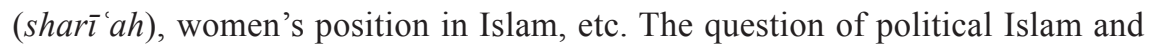
Islam as a religion, its position with regard to the securing of human rights - the position of women in an Islamic society and within Islamic law and the question of minorities in an Islamic nation - has attracted the attention of academia for decades, if not centuries, and the debate is ongoing. Some argue that "Muslims today are involved in a serious argument about political ethics"18 and that "the politicizing of religious thought is often considered to be a characteristic inherent in Islam". ${ }^{19}$ Others recognise that "this politicization has only emerged in the last quarter of the twentieth century as a deliberate policy of the post-colonial nations" ${ }^{20}$ It is also argued that Islam cannot be reconciled with democracy and human rights ${ }^{21}$ and that the position of women and non-Muslims is inherently unequal in Islam. ${ }^{22}$ Some argue that the idea of a democratic religious government is preposterous ${ }^{23}$ and perceive Islamic society as one that incorporates inequality, theocracy, the 
absolute authority of the jurisconsults ( $m u f t i \bar{s}$ ), and use of the death penalty, etc. ${ }^{24}$ In contrast, others argue that some rights (for example, civil or political), embodied in modern democracy, do not guarantee socio-economic-cultural wellbeing and the economic freedom of the market place can be a threat to human rights, just as is political repression, ${ }^{25}$ and Islamic revivalism is a response to the failure of secular leaders in their own countries, ${ }^{26}$ which is the main current focus of political Islam.

With respect to political discourse, in Islam the nature of political thought is a dangerous and contested issue, as Lahoud ${ }^{27}$ suggests. She supports the idea of Muhammad Amara that "in the Islamic tradition, political rule has not been limited to a determined set of criteria, nor for that matter have rulers conformed to a specific and unified code of conduct said to be Islamic". ${ }^{28}$ In contrast, Islamist ideology suggests that Islam indeed has a political manifesto. Selected verses have been used to indicate the orders of Allah. Others suggest that, "the meaning of the text is often only as moral as its reader. If the reader is intolerant, hateful, or oppressive, so will be the interpretation of the text" 29 "but the text does not command such intolerance". ${ }^{30}$ Besides this, soberness in the practice of religion is the utmost demand of a religious society and such religiosity can establish and guarantee the hallmark of both the religious and democratic character of a government. ${ }^{31}$ Inter- and extra-religious domains need to be harmonised, along with liberty and willing participation in democracy, ${ }^{32}$ which can introduce flexibility and tolerance. Soroush ${ }^{33}$ once again recognises that with questions of democracy in Islam a stronger connection is forged in some explanations, and he ${ }^{34}$ further suggests that three dark and dangerous errors dim the horizon of such assessments. For example, democracy has been equated with extreme liberalism, whereas the shari ' $a h$ is considered entirely synonymous with Islam. ${ }^{35}$ From its theoretical ground, democracy restricts the power of rulers in rationalising their deliberation and policies. However, a society that lacks education, is unfamiliar with its rights or is unable to attain them will be deprived of the right to choose and consequently will fail to achieve democracy. Democracy is a choosing process, which could be achieved through a long period of moderation, discussion, offering various freedoms, elections, etc. From a religious point of view, religion needs innumerable subsequent decisions, discussion and arduous trial. In both cases (i.e. Western democracy and Islamic rule), successful efforts depend on the leaders of a nation. Therefore, we see some nations suffering from ill-practice although the citizens vote and elect their representatives. Likewise, we see some autocrats and power-hunting rulers in the name of Islamic rule. Islamic scholars invoke "democratic concepts and ethical constructs within the Islamic tradition, including ijtihād (independent reasoning), shūra (consultation), ijm $\bar{a}$ ' (consensus of the 'ulama', the religious scholars), and bay 'ah (oath of allegiance, while at the same time holding the leaders to certain standards of accountability)". ${ }^{36}$ In other words, religion needs constant examination through "difficult cycles of 
constriction, expansion, modification and equilibrium", ${ }^{37}$ which indicates that the modern democracy already exists within Islam.

At its most conservative, Islam is the opposite of modern globalisation and some adherents flatly deny the universal validity of a global moral vision or global culture. The Islamic discourse, however, recognises the opportunity for Islamisation, and holds that Islamic civilisation can always be reconstructed, reinvented and renewed ${ }^{38}$ and this can be an alternative to the Western secular model, which excludes Islam, ${ }^{39}$ at a time when popular faith in a secularised idea of modern progress has widely collapsed. ${ }^{40}$ Beside this, the Islamic notion of community (ummah) "acknowledges and respects diversity but emphasizes unity"41 and "the idea of ummah is imagined and constantly renewed". ${ }^{42}$ While some argue ${ }^{43}$ that as sharì $a h$ is a "historically conditioned human interpretation of the fundamental sources of Islam, alternative, modern interpretations are possible" 44 which recognises that renegotiation regarding Islam and international human rights standards is also possible. ${ }^{45}$ 'Alī b. Abī Ṭālib, the cousin and son-in-law of the Prophet Muhammad and the fourth of the 'Rightly Guided Caliphs' Islam, suggests that 'this is the Qur'ān, written in straight lines, between two boards [of its binding]; it does not speak with a tongue; it needs interpreters and interpreters are people" ${ }^{46}$ Therefore, it is recognised that interpretation and discussion are important in Islam. The suggestion is that people are not free from their circumstances, so the interpretation depends on the people involved, which is also a reality for any political system.

In this regard, with respect to the Islamists' point of view regarding Islam and the West, Tibi ${ }^{47}$ holds that their arguments for "a place for Islam in the Western society", while rejecting the call to embrace the "idea of Europe", suggest that European multiculturalists fail to understand the arguments of the Muslims. Islamist groups are not fully against what constitutes modernism ${ }^{48}$ and "we hear many Islamists call for democracy" ${ }^{49}$ In this connection, it is also worth considering the statement of Nobel Prize laureate Orhan Pamuk made to Nathan Gardels, ${ }^{50}$ editor of the New Perspective Quarterly, while discussing the political environment of the Muslim world with respect to the political situation in Turkey:

This idea of incompatibility of Islam with modernity is an argument that adopts the fundamentalist logic. Liberals, democrats or Western thinkers should stop making general, vulgar and essentialist observations on Islam every time they come up with some new problem, most of which is partly their making, too.

As to the question of other people's religious rights, the foundation of liberty and freedom of worship has been guaranteed for non-Muslims living in an Islamic state, ${ }^{51}$ as the Qur'ān says, "Lo! Those who believe, and those who are Jews, and Christians, and Sabaens - whoever believe in Allah and the Last Day, do the right 
things, surely their reward is with their Lord, and there shall be no fear come upon them, neither shall they grieve." ${ }^{52}$ Another quote might be worth mentioning:

Say Ye: 'We believe in Allah and what has been revealed to us, and what was revealed to Abraham and Ishmael, and Isaac and Jacob and [his] children, and what was given to Moses and Jesus, and what was given to [all other] Prophets from their Lord. We make no differences between any of them; and to him we submit ourselves. ${ }^{53}$

Regardless of race, colour, sex, and social position, Islam establishes equal rights before the law. The zakāt (alms tax) system ensures the right of the poor of a society as the rich have the obligation to pay zakät, which will be distributed to the poor. Therefore, "Islam encourages private property but limits it by strictly prohibiting usury", and provides social and economic rights through the obligation of zakāt..$^{54}$ Besides the multi-dimensional and ongoing debates regarding the fitting and proper interpretation of shari ' $a h$ - the application of the sharì $a h$ in modern society the main concern of the shari 'ah is the maintenance of proper and harmonious relationships in and across all levels, with the ultimate emphasis being on humanity. ${ }^{55}$ In addition, according to the shari $\bar{i}^{\prime} a h$, rulers are the brothers of their subjects. ${ }^{56}$ Therefore, the meaning of ummah could be recognised as a community under a shared normative framework - the product of understanding and communication.

Currently, women's rights relating to marriage, divorce and child support (for example, Indonesia) ${ }^{57}$ and participation of women in politics (for example, in Kuwait) have advanced from the province of extreme conservatism and have improved because of the modernisation of Islamic law. Previously, the status of women in Arabia (and what we have seen in Europe) in the jähiliyyah period, the pre-Islamic 'Age of Ignorance', had been drastically curtailed. Against what were fearful and ignorant customs and injustice, the Qur'ān stood out in defending women, their place and duties, rights and responsibilities. "In the Qur'ān, women are completely independent entities and fully responsible human beings. The Qur'ān addresses women directly and does not approach her through a third person nor through agents, or through the agency of Muslim males" 58 and in the Qur'ān the noble status and rights of women are explicitly addressed and it is recognised that men and women are created to offer love and company to one another. The Prophet Muhammad repeatedly said: "Women are but the full-counterpart of men", 59 and a woman assumes full responsibility, capability and liability once she has attained

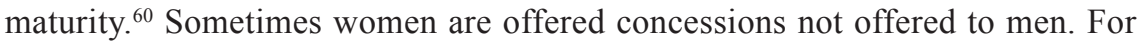
example, during her menstrual period, and the forty days after childbirth a woman is exempted from daily prayer and fasting, and this time might be longer (never less) depending on her condition. On the other hand, the "Qur'ān made it difficult for any Muslim rulers or ruled to deny the noble status of women and her rights, political or other. [...] Denying such rights is a sign of social, political and moral 
dislocation and a deviation from the teaching of Islam. ${ }^{\prime 61}$ Islamic scholars have stated that Islam offers and guarantees freedom of learning, expression, and the freedom to undertake scientific research in all fields of study ${ }^{62}$ and, therefore, the position of Islam is not to keep its adherents prisoners of ignorance. Besides this, it is recognised in the Qur'ān (30:30) that every human being is created "innocent, pure, true, and free, inclined to right and virtue and endued with true understanding about $[\ldots]$ his $\left[\right.$ or her] true nature $[\ldots] .{ }^{963}$

Some suggest there is an Islamic renaissance, that Islamic practices, with respect to women and human rights, are being revamped and secularised ${ }^{64}$ However, when the International Covenant on Civil and Political Rights was approved in the 1950s Muslim representations were ignored and Islamic traditions were not considered. ${ }^{65}$ This document come-up from a monolithic corner (i.e. the West) and all other corners were ignored. Since the 1980s, Muslim scholars have been exploring the relation between Islam and international human rights ${ }^{66}$ Later, the Cairo Human Rights Declaration of August 1990, with representations by Muslim leaders and scholars, created a new bridge between secular notions of human rights and religious notions, ${ }^{67}$ and this declaration demonstrated wider cooperation in the area of general human rights. ${ }^{68}$ In the meantime, some Islamic states (Indonesia, for example) had recognised the Universal Declaration of Human Rights and had included it in their constitutions ${ }^{69}$ and Muslim nations contributed to the formulation of "public international law through their active participation in the United Nations". ${ }^{70}$ Under this process some argue that, "Islam is compatible with democracy and civil society if Muslims want this" "71 and those who think Islam and civil society are incompatible, and so make Islam questionable, are mistaken. This harms Islam, Muslims and our society as a whole. ${ }^{72}$

In this connection, we need to recognise that democracy is neither simply the rule of the majority nor a mere procedure of voting: it is a political culture of pluralism. ${ }^{73}$ In addition, Islamic communities need a culture of democracy and democracy cannot be imposed from outside. The world, perhaps, already has evidence that democracy cannot be established by destroying a regime, or by placing it under extreme or external pressure. From a different angle, it can be said that Western approaches to political communication (i.e. political participation) cannot simply be adopted just anywhere ${ }^{74}$ as there is a need to understand social patterns and values. Otherwise, "to ask only about formal processes, about elections and public opinion, is to miss a range of informal politics $[\ldots] " .{ }^{75}$ Democracy, participation, communication and interaction all involve the practice and ethos of an entire people,${ }^{76}$ and are maintained because they see it as priceless, which offers commentary on the health of political communication nationally and internationally.

Islamic communities also need better education (not really that sort of education which is explicitly imposed by the West), education that is not only grounded in 
their culture, but also opens their eyes to the West. They need to be educated to understand their rights first, to be able to conceptualise and perceive the meaning of democracy and the place of religion in their society. Islam can be compatible with democracy, but it depends on the accountability and morality of the leaders, as in modern democracy, and "Islam can replace nationalism as a basis for legitimacy and allegiance if it is permitted to do so by individuals, groups and states, but it shows no sign of replacing the state." $" 77$ Societies both in the past and the present, however, have misinterpreted and misapplied Islamic law, or sharì $a h$, in favour of repressing "patriarchal non-democratic regimes", ${ }^{78}$ and this has also made Islam controversial in terms of democracy. In addition, the 'theology' of Osama bin Laden, 'Talibanism' and the current popular jihadist organisations is dangerous not only for democracy but also for human civilisation. An egocentric psyche, intolerance and sense of supremacy or 'Puritanism' have all hampered our civility and civilisation. Therefore, Islam should be considered compatible with democracy, but it depends on how Muslims interpret religious rules and on the morality and honesty of their own rulers.

\section{'Jihadism' in Politics}

The current 'popular jihād' of, for example, the Al-Qaeda brand, which has altered the concept of state relations and national policies and politics will be discussed here. However, to recognise the trajectory of this type of ' $j i h \bar{a} d$ ' some other issues will be addressed in an attempt to clear up any misunderstanding caused by the current focus on 'popular jihād'.

The qur'ānic terms harb and al-qitāl are used to define 'war' per se. Qur'ānic terms usually have their own connotations ${ }^{79}$ and the word jihād does not mean 'holy war', but struggle or effort, ${ }^{80}$ and "where jihād does refer to resistance to oppression, it is also not all of one kind, but embraces both armed and unarmed forms of struggle". ${ }^{81}$ Some people, however, used the words for war interchangeably with the word $j i h \bar{a} d$. Consequently, a great deal of misunderstanding regarding Islamic law arises from the confusion regarding the concept of $j i h \bar{a} d,^{82}$ and this issue has affected both Islamic and Western societies and has had a significant impact on world mass media and scholars. The West sees any movement promoted or propagated by Muslims as ' $j i h \bar{a} d$ ' and translates the term in such a way as to mean terrorism, extremism or fundamentalism, which are not the meanings of classical jihād in Islam. Jihäd actually means that a person should endeavour to lead a good Muslim life, follow the orders of Allah, be an attentive husband or wife, and be responsible to parents and family, to other human beings and to everything. ${ }^{83}$ It also means to fight or struggle in favour of the weak and to help them if possible. However, currently this idealistic meaning has been altered and a very negative perception has been 
formed which has affected and replaced the exact meaning. In the colonial era, Arabs encountered the West in the same way as today, and opposed the West's cultural modernity and colonial ideas. The purpose of this movement to resist colonisation was mainly to oppose European ideas. ${ }^{84}$ It was a jihād to Muslims against the West to indicate their dissatisfaction with Western hegemony and cultural modernity, together with a desire for national sovereignty. Besides this, in the context of the 'war on terror', which, supposedly, is being fought to combat 'jihadism', if Osama bin Laden were to be captured and the Al-Qaeda terrorist network disappears, 'Islamic jihadism' would remain present. ${ }^{85}$ Arguably, this popular 'jihadism' creates political disorder around the world in general and undermines the integration of Muslims in Europe in particular. This 'jihadism', however, is similar to the leftists' activities that originated in Europe. If we look back on the current world order, for example, we will see that the call of Bin Laden's 'jihadism', which has turned the West's focus onto the whole Muslim community, is "borrowed directly from the extreme Left of the 1970s, in particular from the staging of the 'trial' of Aldo Moro by the Italian Red Brigades in 1978".86

From a classical point of view, "Muslims are enjoined to act, to struggle (jihād) to implement their belief, to lead a good life" ${ }^{87}$ In some Western media, however, the meaning of jiha $\bar{d}$ is misinterpreted and Islam is portrayed as a threat to the West, and the Western media presents Islam as associated with fundamentalism and terrorism, ${ }^{88}$ and this association has also become enrooted in the wider mind of the world. In this connection, the political jihadist groups' demonstrations have violated the meaning of the classical jihād of Islam, to wit the declaration of a ' $j i h \bar{a} d$ international' by Al-Qaeda. They, however, declared jihād against governments in the Muslim world and attacked Western representatives and institutions in the region, but now the United States and the West are their primary targets in an unholy war of terrorism. ${ }^{89}$

Some earlier world events might be remembered in this context, to clarify the jihadist formation. The failure of the Arabs in the Arab-Israel Six Day War of 1967, a similar result in the 1973 war between Egypt and Israel, and the oil embargo against the Arabs, are events that have been followed with mixed feelings by Arabs. The later Islamic revolution in Iran might have engendered more positive feelings, and a sense of pride in the Islamists' mind, for "the discussion of recent socioreligious practices as Islamic fundamentalism started quite abruptly after the Iranian revolution in 1979"..$^{90}$

This sort of spirit continued when, in 1979, a group of militants, who called for the overthrow of the Saudi royal family, attacked the Grand Mosque in Mecca. ${ }^{91}$ They wanted to 'purify' Islam and return to 'traditional' Islam - a 'pure' Islamic state and society. Another event that may have fuelled their ambitions was the anti-communist attack in Afghanistan on 27 September 1996, which toppled the 
Soviet-backed government of Najibullah (Muhammad Najīb-Allāh), who was executed by the Taliban. It may be that the Soviet intervention in Afghanistan in 1979 "galvanized Afghanistan's diverse tribal and religious leaders and movement in a popular jihad", ${ }^{2}$ a jiha $\bar{d}$ propagated by residents of a Muslim nation against their own government.

Besides this, from a quasi theological-cum-political point of view, different individuals have brought different approaches to explain the Islamic revelation. Some believe that all Islamic authority resides in the religious texts (the Qur'ān and the hadìth), some recognise that 'development in doctrine is inherent in revelation itself', and others have been driven by passion for primal authenticity. ${ }^{93}$ In this connection, Lahoud ${ }^{94}$ recognises a tri-dimensional current in Islamic thought and activity, comprising apologists, intellectuals and Islamists. She ${ }^{95}$ argues that the apologists are currently working on an advanced and alternative interpretation of Islam. They are recognised as liberal and are highly appreciated for their intellectual endeavour around the world. The second stream of Lahoud's current, the intellectuals, Lahoud ${ }^{96}$ describes as those whose understanding of Islamic tradition is not exclusively through the lens of foundational religious texts, but rather whose explanation started from the landscape of contemporary concerns of the world, and "who designate themselves as intellectual (muthaqqafin) by virtue of their exploration of these concerns". They are also known as the contextual stream.

The third stream of Lahoud's current is the Islamists. This current is well known and popular with the general public and is very active ideologically. They have a strong political ideology and operate actively from a political platform based on a particular Islamic tradition. 'Jiha $\bar{a}$ ' is a term that might be used as their extreme expression. They selectively use the Qur'ān and the hadith as tools to justify their political ideology and emphasise their faithful adherence to the Islamic foundation texts. ${ }^{97}$ They are also called the 'textual stream'. This group also uses religious norms, symbols and other religious phenomena as a tool of politics. ${ }^{98}$ Yet, the Prophet has assigned great importance to motive (what, why and how), which is neglected in most of the cases in the attempt of these popular jihadists to ignore Prophetic injunctions against killing innocent people, for example. ${ }^{99}$ These idealist meanings of Islamic spirit, nonetheless, have been violated through popular jihadism.

In addition, politics is a controversial issue among Islamic thinkers (mentioned earlier). In this connection, references, which have been recognised by Khatab and Bouma ${ }^{100}$ from the ideas of Abū 'l-A ' lā Mawdūdī, Sayyid Quṭb and 'Alī 'Abd al-Rāziq, might be useful. 'Abd al-Rāziq - proceeding from a secular viewpoint was convinced that Allah does not impose upon Muslims a specific type or form of government, but that they are free to choose what is better for the welfare of their society at any time. Al-Rāziq argues that a caliphate is not essential to the Islamic community ${ }^{101}$ as it is not a religious institution and Prophet Muhammad was not a 
king. ${ }^{102}$ Besides this, some “ 'ulamā', including Ibn Taymiyyah, traditionally resisted all kinds of forces which might have potentially led to the kind of state powers which we have seen recently" and politics in Islam "is located predominantly in quite a different arena". ${ }^{103}$ On the other hand, Quțb and Mawdūdī both saw Islam, by its very nature, as a 'political religion'. Quṭb was inspired by Mawdūdī and took a position in Egypt against the regime of Jamāl 'Abd al-Nāșir. He was hanged in 1966 after years of imprisonment and torture, ${ }^{104}$ but successfully communicated his thoughts, which have inspired a number of radical groups. However, these groups do not possess the exact ideology of Quț ${ }^{105}$ as Quṭ himself agreed that Islam was not against democratic constitutional rule. ${ }^{106}$

Unquestionably, in some cases the misinterpretations and misunderstandings in the West about the meaning of ' $j i h \bar{a} d$ ', have come about because of, and been propagated by, the activities of an Islamist current - Islamist jihadism. The current popular jihadism, lying at the hub of world politics, is no longer the same as classical $j i h \bar{a} d$. However, Islam in general and political Islam in particular has been wrongly associated with an understanding of jihäd as terrorism. Through the activities of terrorists, the positive meaning of jiha $\bar{d}$ is currently misunderstood and distorted to mean killing, terrorism, and fundamentalism. Jihäd has currently come to be associated with suicide bombing, the killing of innocent people and other negative issues, although there is a strong obligation in Islam not to kill innocent people and not to commit suicide. Therefore, fanatical Islamic jihadism is divorced from the meaning of classical jiha $\bar{a}$. As it is expressed in Islam, nonviolence is preferred over violence and forgiveness ( 'afw) over retribution. ${ }^{107}$ The Qur'ān declares, "the recompense of an injury is an injury the like thereof; but whoever forgives and thereby brings about a re-establishment of harmony, his reward is with Allah; and Allah loves not the wrongdoers". ${ }^{108}$ Therefore, tolerance is another quality, which is highly appreciated in Islam. However, the meaning of classical jih $\bar{a} d$ has been misquoted or effaced in the explanations (or ignorance) of the popular jihadists and in the West.

In current history, the attack of 11 September 2001 on the United States was a broad-based terrorist activity, which contributed strongly to a negative impression of the idealistic concept of ' jih âd'. However, in the words of Esposito:

Historic memories of the Crusades and European colonialism, the creation of Israel, the Cold War, and American neo-colonialism - all the actions of a Christian West - get superimposed upon current events: the second Palestinian intifada, the presence of American troops in the Gulf, the devastating impact of sanctions on Iraqi children, jihad of resistance and liberation in Kashmir and Chechnya. These memories feed resentment, ignite new anger, and deepen anti-Americanism, not just among terrorists but also in the broader Muslim world. ${ }^{109}$

ICR 2.3 Produced and distributed by Pluto Journals ICR.plutojournals.org 
Also, Tibi ${ }^{110}$ notes that, "Islamists not only want to remake the world through jihad and thus Islamize it, they also engage in an Islamisation of knowledge" and they want to alter the hegemonic power in favour of Islam. ${ }^{111}$ Some argue that in some places active Islamist involvement in 'development projects' has filled a void in national social politics. ${ }^{112}$ Nevertheless, some negative ideas, which have been recognised as a part of Islamist activities by the West, do in fact also run counter to classical Islamic ideology. 'Jihâd' has a profound place in Islamic culture, and both the Qur'ān and the hadìth urge every human being to be prepared for it. This idea of $j i h \bar{a} d$, however, differs from that presented by Western media and contrasts with the ideas of 'popular' political jihadism. This popular jihadism is in no way reflective of the original idea of jihād in Islam. And popular jihadists use qur'ānic edicts to motivate people only to perpetuate their political goal. The political jihadisms have a strong presence in the current world media and social debates across the world, but to recognise political jihadists in this way would mean that the philosophical role of Islamic jiha $\bar{d}$ is misunderstood, which is why religious jihâd in Islam is erroneously equated with political jihadism and both are given the same meaning in popular explanation.

\section{Conclusion}

The issue of human rights and democracy is a contested issue amongst scholars within and outside of the Muslim world. However, both issues can be resolved if Muslims want to. Islam can accommodate democracy and preserve human rights, depending on the interpretation of Islamic rules, qur'ānic verses and others. Also, it is important for leaders to be honest in the application of those rules. Consequently, all citizens will be granted their rights. In addition, Islam and the West need to be closer to each other to understand their concerns and communicate better than they have done in recent years. Belonging to a religion of peace and tolerance, Muslims need to give up the ideology of political (popular) jihadism for a dynamic and peaceful co-existence in any society. They need to conceptualise that Islam can be compatible with democracy if they want it to be. Besides this, Muslims need better education and a culture of political communication, which will allow them to understand their rights in society and in relation to others. They need to conceptualise the essence of Islam and need to leave the idea of political 'jihadist' Islam.

Thus, this discussion ends with the basic platform that what is essentially needed in the emerging world discourse regarding the West and Muslims is on both sides the recognition and understanding that Muslims and the West are compatible and share similar concerns and that mutual understanding will enable integration for mutual enrichment. 


\section{Notes}

1. Federica Bicchi and Mary Martin, "Talking Tough or Talking Together? European Security Discourses Towards the Mediterranean", in: Frederic Volpi (ed.), Transnational Islam and Regional Security: Cooperation and Diversity Between Europe and North Africa (London: Routledge, 2008), 53.

2. Samuel Huntington, "The Clash of Civilizations", Foreign Affairs 72, no. 3 (Summer 1993), $22-49$.

3. Bicchi and Martin, "Talking Tough", 54 .

4. Lars Pedersen, Newer Islamic Movements in Western Europe (Sydney: Ashgate, 1999), 7.

5. Friedemann Büttner, "The Fundamentalist Impulse and the Challenge of Modernity", in: George Stauth (ed.), Islam - Motor or Challenge of Modernity. Yearbook of the Sociology of Islam 1/1998 (Hamburg: Lit Verlag, 1998), 59.

6. Hamadi Redissi and Jan-Erik, "Does Islam Provide a Theory of Violence?", in: Amélie Blom, Laetitia Bucaille and Luis Martinez (eds), The Enigma of Islamist Violence (New York: Columbia University Press, 2007), 44; John Kelsay, Arguing the Just War in Islam (Cambridge MA: Harvard University Press, 2007), 4.

7. Leonardo A. Villalón, Islamic Society and State Power in Senegal: Discipline and Citizen in Fatick (Cambridge: Cambridge University Press, 1995), 15.

8. Bassam Tibi, Islam Between Culture and Politics (Houndmills, Basingstoke, UK: Palgrave Macmillan, 2005, 2nd ed.), xii.

9. John Esposito, quoted in Mohammed Muqtedar Khan, "Islam as an Ethical Tradition of International Relations", in: Abdul Aziz Said, Nathan C. Funk and Ayse S. Kadayifci (eds), Peace and Conflict Resolution in Islam: Precept and Practice (Oxford: University Press of America, Oxford, 2001), 88.

10. Andrew Vincent, "What is so Different about Difference?", in Bruce Haddock and Peter Sutch (eds), Multiculturalism, Identity and Rights (London: Routledge, 2003), 43.

11. Avtar Brah, Cartographies Diaspora: Contesting Identities (New York: Routledge, 1996), 227.

12. Eva Mackey, The House of Difference: Cultural Politics and National Identity in Canada (New York: Routledge, 1999), 70.

13. Mike Featherstone, "Islam Encountering Globalization: An Introduction", in: Ali Mohammadi (ed.), Islam Encountering Globalization (London: RoutledgeCurzon, 2002), 3.

14. George Stauth, "Introduction", in: Stauth (ed.), Islam, 7.

15. Karin Werner, "Deconstructing the Issue of Islamic Fundamentalism: Approaching the Issue", in: Stauth (ed.), Islam, 38.

16. Büttner, "The Fundamentalist Impulse", 75.

17. Stauth, "Introduction", 7.

18. Kelsay, Arguing, 4

19. Jocelyne Cesari, When Islam and Democracy Meet: Muslim in Europe and in the United States (New York: Palgrave Macmillan, 2004), 44.

20. Ibid. and Khaled Abou El Fadl, "Islam and the Theology of Power", Middle East Report 22 (Winter 2001), 6.

21. Charles Kurtzman, "The Globalization of Rights in Islamic Discourse", in: Mohammadi (ed.), Islam Encountering Globalization, 151.

22. Katerina Dalacoura, Islam, Liberalism and Human Rights (London: I.B. Tauris, 2007), 48.

23. Abdolkarim Soroush, Reason, Freedom and Democracy in Islam, transl., ed., intro. Mahmoud Sadri and Ahmad Sadri (Oxford: Oxford University Press, 2000), 133.

24. Ibid., 134.

25. Y. Ghai, "Rights, Social Justice and Globalization in East Asia", in: Joannne R. Bauer and Daniel A. Bell (eds), The East Asian Challenge for Human Rights (Cambridge: Cambridge University Press, 1999), 241-63. 
26. Mahmood Monshipouri, "Islam and Human Rights in the Age of Globalization", in: Mohammadi (ed.), Islam, 94.

27. Nelly Lahoud, Political Thought in Islam: A Study in Intellectual Boundaries (London: RoutledgeCurzon, 2005), 68.

28. Ibid.

29. Khaled Abou El Fadl, The Place of Tolerance in Islam (Boston: Beacon Press, 2002), 23.

30. Ibid.

31. Soroush, Reason, 133.

32. Ibid., 133 .

33. Ibid., 217-18.

34. Ibid., 134.

35. Ibid., 133.

36. Monshipouri, "Islam", 102.

37. Soroush, Reason, 131-55, and passim.

38. Monshipouri, "Islam", 101.

39. B. Beeley, "Islam as a Global Political Force", in: John Anthony G. McGrew and Paul G. Lewis (eds), Global Politics: Globalization and the Nation-State (London: Polity Press, 1992), 310; see also Monshipouri, "Islam".

40. J. Haynes (ed.), Religion, Globalization and Political Culture (New York: St Martin's Press, 1999), 247.

41. Hamid Mowlana, "New Global Order and Cultural Ecology", in: Kaarle Nordenstreng and Herbert I. Schiller (eds), Beyond National Sovereignty: International Communication in the 1990s (Norwood NJ: Alex Publishing), 405.

42. Cesari, When Islam and Democracy Meet, 92 and 179.

43. For example, A. An-Na'im, "Islamic Foundations of Religious and Secular Discourse in Islamic Societies", in: Mahnaz Afkhami (ed.), Faith and Freedom: Women's Human Rights in the Muslim World (Syracuse NY: Syracuse University Press, 1995), 59.

44. Monshipouri, "Islam", 103.

45. Ibid.

46. F. Esack, Qur'an, Liberation and Pluralism (Oxford: Oneword, 1997); Kurtzman, "The Globalization of Rights", 131.

47. Bassam Tibi, Political Islam, World Politics and Europe: Democratic Peace and Euro-Islam versus Global Jihad (London: Routledge, 2008), 191.

48. Ibid., 225.

49. Sami Zubaida, "Trajection of Political Islam", in: Stauth (ed.), Islam, 84.

50. Nathan Gardels, interview with Orhan Pamuk, "The Two Souls of Turkey", New Perspectives Quarterly (Fall 2009/Winter 2010), available online at http://www.digitalnpq.org/archive/2009_ fall_2010_winter/10_pamuk.html (accessed on 22 March 2010).

51. Ali Mohammadi, "The Culture and Politics of Human Rights in the Context of Islam", in: Mohammadi (ed.), Islam, 117.

52. Qur'ān 2:62; see also Mohammadi, "The Culture”, 117.

53. Qur'ān 2:136; see also Mohammadi, "The Culture”, 117.

54. Dalacoura, Islam, 47.

55. Abdul Aziz Said, Nathan C. Funk, and Ayse S. Kadayifci, "Islamic Approaches to Peace and Conflict Resolution”, in: Said, Funk and Kadayifci (eds), Peace, 8.

56. Sayed Khatab and Gary D. Bouma, Democracy in Islam (London: Routledge, 2007), 101.

57. Monshipouri, "Islam", 100.

58. Khatab and Bouma, Democracy, 114-15.

59. Rị̣ā, Huqūq al-nisā', quoted in Khatab and Bouma, Democracy, 116.

60. Jamal Nasir, The Islamic Law of Personal Status (Norwell MA: Kluwer Law International, 2002), 50-1; see also Khatab and Bouma, Democracy, 116.

61. Khatab and Bouma, Democracy, 128. 
62. Mohammadi, "The Culture", 117.

63. Meena Sharify-Funk, "Peace and the Feminine in Islam", in: Said, Funk, and Kadayifci (eds), Peace, 279.

64. Cesari, When Islam and Democracy Meet, 180.

65. Mohammadi, "The Culture", 112.

66. Ann Elizabeth Mayer, Islam and Human Rights: Tradition and Politics (Boulder CO: Westview Press, 2007, 4th ed.), 11.

67. Mohammadi, "The Culture", 114.

68. Hossein Mehrpour, Human Rights as International Instrument and the Position of the Islamic Republic of Iran (Tehran: Ettela'at), quoted in Mohammadi, "The Culture", 114.

69. N.A. Fadhil Lubis, "Islamic Perspectives on the Rule of Law and Constitutionalism", in: Azyumardi Azra and Wayne Hudson (eds), Islam Beyond Conflict: Indonesian Islam and Western Political Theory (Burlington VT: Ashgate, 2008), 21.

70. Mayer, Islam, 12.

71. Tibi, Political Islam, 234.

72. Ibid., 234.

73. Ibid., xiii.

74. Anabelle Sreberny, "The Analytic Challenges of Studying the Middle East and Evolving Media Environment", Middle East Journal of Culture and Communication 1 (2008), 14.

75. Ibid.

76. J. Stout, Democracy and Tradition (Princeton: Princeton University Press, 2004).

77. Beeley, "Islam", 310.

78. Khatab and Bouma, Democracy, 210.

79. Ibid., 176.

80. Rabia Terri Harris, "Nonviolence in Islam: The Alternative Community Tradition", in: Said, Funk, and Kadayifci (eds), Peace, 228.

81. Ibid.

82. Khatab and Bouma, Democracy, 176.

83. John L. Esposito, Unholy War: Terror in the Name of Islam (Oxford: Oxford University Press, 2002), 5 .

84. Tibi, Political Islam, 5.

85. Ibid., 9 .

86. Oliver Roy, Secularism Confronts Islam [in French], translated [in English] by George Holoch, 2005, (New York: Columbia University Press, 2005), 90.

87. Esposito, Unholy War, 5 .

88. O. Awass, "The Representation of Islam in the American Media", Hamdard Islamicus 19, no. 3 (1996), 87-102.

89. Esposito, Unholy War, $\mathrm{x}$.

90. Shmuel N. Eisenstad, "Sectarianism and the Dynamics of Islamic Civilization", in: Stauth (ed.), Islam, 37.

91. J.M. Berger, The Siege at Mecca: A Sourcebook for Researchers (Oxford: Intel Wire Press, 2006).

92. Esposito, Unholy War, 9 .

93. Anthony H. Johns and Nelly Lahoud, "The World of Islam and the Challenges of Islamism", in: Nelly Lahoud and Anthony H. Johns (eds), Islam in World Politics (London and New York: Routledge, 2005), 7.

94. Lahoud, Political Thought.

95. Ibid., 13 .

96. Ibid., 3 .

97. Ibid., 13.

98. Büttner, "The Fundamentalist Impulse", 75.

99. Harris, "Nonviolence", 238.

100. Khatab and Bouma, Democracy, 9. 
101. Eric Winkel, Islam and The Living Law: The Ibn Al-Arabi Approach (Oxford: Oxford University Press, 1997), 8.

102. Dalacoura, Islam, 92.

103. Winkel, Islam, 3.

104. Anthony H. Johns, "Let My People Go! Sayyid Qutb and the Vacation of Moses", Islam and Christian-Muslim Relations 1, no. 2 (1990), 143-70.

105. Johns and Lahoud, "The World of Islam", 13-14.

106. Khatab and Bouma, Democracy, 76.

107. Said, Funk and Kadayifci (eds), 8.

108. Qur'ān 42:40; see also Said, Funk and Kadayifci (eds), Peace, 8.

109. Esposito, Unholy War, 73-4.

110. Tibi, Political Islam, xix.

111. Tibi, Islam, 92.

112. J.H. Mittelman and M.K. Pasha, Out from Underdevelopment Revisited: Changing Global Structures and Remaking of the Third World (New York: St Martin's Press, 1997), 95. 